\title{
KASVATUS KANSALAISUUTEEN
}

\section{- kansalaiskoulun unohdettu missio}

\author{
Kulkemani tutkimusmatka ${ }^{l}$ kansalaiskoulun historiaan on saanut minut \\ katsomaan 'uusin silmin' tämän päivän koulutuskeskustelua. Koulutuk- \\ sen perusluonteeseen ankkuroituva ongelma teoreettisen ja käytännölli- \\ sen opetuksen välisestä suhteesta sai erityisen painoarvon tässä työväes- \\ tön nuorten ja ruumiillisen työn tekijöiden koulussa, jossa myös kysymyk- \\ siä kansalaisuudesta ja siihen kasvattamisesta määriteltiin suhteessa \\ käytännölliseen opetukseen, ammatilliseen koulutukseen ja työelämään.
}

\section{ANNUKKA JAUHIAINEN}

L ähihistoriastamme kansalaiskoulu oli sellainen koulutuksen ja työn välimaastoon sijoittunut koulumuoto, josta käydyssä keskustelussa painottui erityisesti kasvaminen kansalaisuuteen. Olen tarkastellut kansalaiskoulua väitöskirjatutkimuksessani "Työväen lasten koulutie ja nuorisokasvatuksen yhteiskunnalliset merkitykset. Kansakoulun jatko-opetuskysymys 1800-luvun lopulta 1970-luvulle"2. Teoreettispainotteisen ja statukseltaan korkeamman oppikoulun varjossa kansalaiskoulu tuotti oman vaihtoehtoisen kasvatusohjelmansa, jossa oppimisen perustaa - tietämistä ja taitamista - ei irrotettu työn ja käytännön maailmasta.

Vaikka varsinainen kansalaiskoulu luotiin suomalaiseen koulutusjärjestelmään vasta 1950-luvun lopulla, sen juuret jatkokursseineen ja -kouluineen ulottuvat aina 1800-luvun loppupuolelle. Tuolloin, 1800-luvun lopulla ja 1900-luvun alussa, käytettiin nimitystä kansakoulun jatkoopetus. Se tarkoitti kaupungeissa usein yksivuotisia jatkokouluja ja maaseudulla vaihtelevanpituisia jatkokursseja. Oppivelvollisuuden säätämisen myötä kansakoulun jatko-opetuksesta tuli periaatteessa pakollista, oppivelvollisuuteen sisältyvää koulutusta. Oppivelvollisuuslakia seuranneina vuosikymmeninä kansakoulun jatkoopetuksesta käytiin kiivasta keskustelua, jossa tälle nuorisokoululle etsittiin sopivaa muotoa ja sisältöä. Olen artikkelissani nostanut esiin erityisesti tyttöjen kotitalousopetuksen, jolla toteutettiin erityistä naiskansalaisuuden kasvatusohjelmaa. Sotien jälkeiseen aikaan voidaan ajoittaa tämän koulumuodon lyhyt kultakausi, jolloin myös kansalaiskasvatus kytkettiin tiiviisti työkasvatukseen ja käytännön taitojen arvostukseen.

Kulkemani tutkimusmatka kansalaiskoulun historiaan on saanut minut katsomaan 'uusin silmin' tämän päivän koulutuskeskustelua. Jatko-opetuksen ja kansalaiskoulun historia tarjoaakin mielenkiintoisia näkökulmia mm. nuorisokoulukysymykseen, kansalaiskasva-

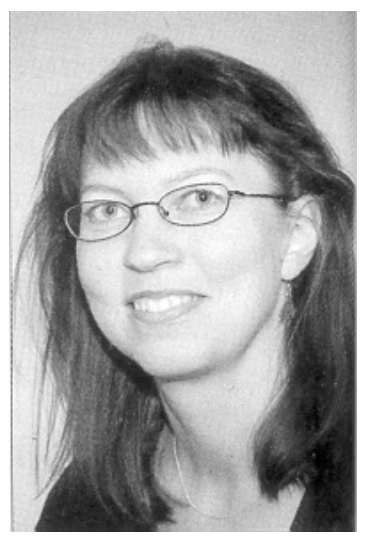

Annukka Jauhiainen tukseen ja koulutuksen mahdollisuuksiin syrjäytymisen ehkäisijänä. Koulutuksen perusluonteeseen ankkuroituva ongelma teoreettisen ja käytännöllisen opetuksen välisestä suhteesta sai erityisen painoarvon tässä työväestön nuorten ja ruumiillisen työn tekijöiden koulussa, jossa myös kysymyksiä kansalaisuudesta ja kansalaisuuteen kasvattamisesta määriteltiin suhteessa käytännölliseen opetukseen, ammatilliseen koullutukseen ja työelämään.

\section{KANSALAISKOULUN ENSIASKELEET KANSAKUNNAN RAKENTAMISPROJEKTISSA}

Kansalaiskoulun edeltäjä, jatkokoulu, oli yleissivistävän kansakoulun ja varsinaisen ammattikoulun välissä toimiva ja vaihtelevassa määrin itsenäinen koulumuoto. Sen tehtävät olivat kahtalai- 
set: valmistaa oppilaita ammattiin ja kasvattaa heistä kelvollisia ihmisiä ja kansalaisia. Peruskysymys kuuluikin, millaista kasvatusta kansalaisuuteen ja työelämään ruumiilliseen työhön siirtyvät nuoret tarvitsivat. Jatko-opetuskeskustelu käynnistyi Suomessa varhain ja tilanteessa, jossa kansakoulunkäyntikään ei ollut vielä vakiintunut. Virikkeitä keskusteluun saatiin ulkomailta, missä oli kokeiltu erilaisia malleja työväestön nuorten koulutuksen pidentämiseksi ja tehostamiseksi. Varhaiset perustelut liittyivät kansakoulun käyneiden huonoon tiedolliseen tasoon ja kansakoulun "epäonnistumisen" katsottiin ainakin osittain johtuvan oppilaiden iästä. Kansakoulun päättäneet olivat liian nuoria ja kypsymättömiä ja siksi koulutus haluttiin ulottaa kehittyneempään ikäkauteen, jolloin opetusta voitaisiin paremmin ymmärtää ja hyödyntää tulevassa aikuiselämässä. (Englund 1986; McCulloch 1998; Jauhiainen 2002, 101-107.)

Erityisen tulisieluisen puolestapuhujan kansakoulun jatko-opetus sai 1900-luvun alkupuolen vaikutusvaltaisesta fennomaanipoliitikosta ja kansakoulumiehestä Mikael Soinisesta ${ }^{3}$, joka perusteli jatko-opetusta vuonna 1911 ilmestyneessä kirjassaan näin:

"Tässä on puhe sen nuorison sivistystarpeista, joka ei koskaan astu jalkaansa oppikouluun eikä varsinaiseen ammattikouluun. Se on ainakin $90 \%$ kansan kasvavaa polvea. Tämän valtavan enemmistön oloista olemme tähän saakka sangen vähän huolineet ja huolehtineet, sen jälkeen kun kansakoulun ovi on sen takana sulkeutunut. Sen ehkä ratkaisevimmat kehitysvuodet ovat jääneet kaikkea yhteiskunnan huolenpitoa vaille. Mutta se se kuitenkin muodostaa muutaman vuoden perästä kansan pääosan, jonka sivistyskannasta lopultakin ja ennen kaikkea jää riippumaan kansan kunto - tai sen kunnottomuus. Ja tämä seikka se antaa nykyajan heräävälle huolenpidolle nuoruusiän sivistystarpeista sen ylen suuren merkityksen." (Soininen 1911, 6-7.)

Soinisen puheenvuorosta voimme poimia muutaman keskeisen jatko-opetukseen liitetyn seikan: ensinnäkin kysymys oli koulutuksen kautta tapahtuvasta yhteiskunnallisesta huolenpidosta, yhteiskunnalla oli oikeus ja velvollisuus kantaa vastuunsa tulevista kansalaisista pitämällä heidät pidemmän aikaa koulun suojelevien seini- en sisäpuolella. Toiseksi, kysymys oli kansan kunnosta tai kunnottomuudesta eli juuri kunnon kansalaiseksi kasvattamisesta. Riittävä sivistystaso oli turvattava, jotta saatiin kansalaisoikeutensa ja -velvollisuutensa oikealla tavalla ymmärtäviä yhteiskunnan jäseniä. Kolmanneksi: nuoruusikä nähtiin erityistä suojelusta kaipaavana ikäkautena, jolloin luotiin perustus koko tulevalle elämälle. Yhteiskunnallisen ja kansalaiskasvatuksen kannalta nuoret elivät etsikkoaikaansa koulun maailman ja työn maailman välimaastossa.

Mikael Soininen puhui nuorison sivistystarpeisiin vastaamisesta "vuosisadan suurena tehtävänä, joka kuuluu kaikille sivistyskansoille, mikäli ne tahtovat menestyä. Uudenlainen aktiivinen ja vastuullinen kansalaisuus sai perustelunsa sekä kansalaiselämän että työelämän lisääntyvistä vaatimuksista. Äänioikeuden saaminen ja yleisen kansanvaltaisuuden lisääntyminen edellyttivät yhteiskunnallista kasvatusta. Toisaalta työelämässä vaadittiin yhä enemmän tietoja ja taitoja:

’...ei missään ammatissa nuori polvi voi enää jättäytyä yksinomaan tämän käytännöllisen valmistuksen varaan. Sen täytyy oppia myöskin tietopuolisesti ymmärtämään ammattiansa ja käyttämään hyväkseen niitä apuneuvoja, joita tiede tai taide hänelle tarjoaa... Se ammatti, jonka nouseva polvi ei saa riittävää ajanmukaista valmistusta, se rappeutuu ja menettää kilpailukykynsä. Ja niin koko kansa tältä kohdalta jääpi takapajulle nykyajan ankarassa taloudellisessa kilpailussa muiden kansojen kanssa." (Soininen 1911, 10-11.)

Soinisen esittämät perustelut kuulostavat varsin moderneilta: nuoruusiän pidemmän ja perusteellisemman koulutuksen tärkeä vaikutin oli taloudellinen kilpailu. Myös käytännöllisissä ammateissa tarvittiin Soinisen mukaan koulutettua työvoimaa, jotta kansainvälinen kilpailukyky turvattaisiin. Soininen katsoi, että työväestön sivistystasoa oli mahdollista nostaa luomalla omaleimainen työväestön koulu, jossa yhdistettiin tietopuolinen ja käytännöllinen opetus.

Kysymys oli samalla kasvatusvastuun uudenlaisesta jakamisesta vanhempien ja yhteiskunnan kesken. Tähän kysymykseen muutamaa vuotta aikaisemmin työskennellyt oppivelvollisuuskomitea oli ottanut selkeän kannan. Yhteiskunnan valta lasten kasvatuksessa oli tunnustettu. Oppivelvollisuutta perusteltiin sillä, että yhteiskun- 
nan oli turvattava riittävä sivistystaso ja suojeltava alaikäisiä "ymmärtämättömiä ja huolimattomia vanhempia vastaan”, elleivät nämä käsittäneet koulutuksen merkitystä. (Kom 1907, 4-5.)

Kaupungeissa jatko-opetus yleistyi ensimmäisenä suuremmissa teollisuuskaupungeissa, joissa myös kansakoululaitos oli pitkälle kehittynyt ja koulunkäynti vakiintunutta. Maaseudulla jatko-opetusta järjestettiin erillisinä jatkokursseina, joilla saattoi opiskella myös varttuneempaa väkeä. Soininen oli jo 1800-luvun lopulla vetänyt kansakouluopettajia mukaan myös aikuiskasvatustehtäviin suunnitellessaan maaseudun jatkokursseista välinettä kansanvalistustyön edistämiseen. Esimerkiksi Valvojaan vuonna 1899 kirjoittamassaan artikkelissa hän suunnitteli kolmiportaisen aikuisrahvaan kansanvalistusjärjestelmän maaseudun oloihin. Kansan valistaminen tarkoitti ennen kaikkea kouluopetuksesta osattomaksi jääneen aikuisväestön - kansan syvien rivien - opetusta. Tämä "kansakoulun laajennusliikkeeksi" nimetty ohjelma sai innostuneen vastaanoton 1800- ja 1900 -lukujen taitteessa ensimmäisen sortokauden jälkimainingeissa ja kansakoulunopettajat paikkakuntien muun sivistyneistön tuella pistivät kilvan pystyyn kotikouluja, kansanopistokursseja ja jatkokursseja. Toiminta hiipui kuitenkin nopeasti alkuinnostuksen jälkeen - kansan syvien rivien opiskelumotivaatio ei riittänyt kovin pitkäjänteiseen ja ponnisteluja vaativaan työskentelyyn. (Johnsson 1899b, 264-267; Kansakoulukokous 1899, 42-46; Kansakoulun Lehti 1901, 58-59, 60-63.)

Soinisen kiinnostus käytäntöön suuntautuneeseen jatko-opetukseen kohtaan ilmensi hänen laajempaa kasvatuksellista tavoitettaan valjastaa kasvatus ja koulutus elämässä hyödyllisten tietojen ja taitojen palvelukseen. (ks. esim. Johnsson 1899a.) "Elämälle tarpeellisesta" kehittyi Esko Nikanderin mukaan Soiniselle keskeinen kasvatustavoite. Jo vuonna 1897 Keski-Eurooppaan tekemällään matkalla hän pohti kysymystä siitä, kuinka koulutuksen vaikutus näkyy kansan arkielämässä ja kiinnitti huomiota mm. kulttuuriympäristöjen siisteyteen ja viihtyisyyteen, työväestön asenteisiin ja sen suhteeseen sosialismiin. Näiden kokemusten on nähty saaneen Soinisen arvioimaan kriittisesti Suomen kansakoulujen opetussisältöjä ja näkemään käytännöllistä elämää palvelevien oppisisältöjen ja -aineiden arvon. Arkielämää hyödyttävän kasvatuksen ajatus ei edes ollut Soiniselle mikään uusi; siveellisyys ja siveellinen luonne Soinisen keskeisenä kasvatuspäämääränä piti sisällään hyödyllisyyden ja lähimmäistensä palvelemisen. (Nikander 1989, 7880.)

Tässä yhteydessä on syytä muistuttaa niin 'siveellisyys' - kuin 'sivistys'-käsitteiden aikasidonnaisuudesta. Siveellisyydellä oli 1800-luvulla ja 1900-luvun alkupuolella varsin laaja merkitys ja se liitettiin ennen kaikkea yksilön vastuullisuuden kasvattamiseen kansalaisena. "Siveellisen luonteen" kehittäminen oli aikakauden keskeisiä tavoitteita. Siveellinen ihminen merkitsi ihmistä, joka pysyi vakaumuksensa takana ja jolla oli ymmärrystä yhteiskunnallisen vallan käyttämiseen. Sivistys-käsitteen taustalla oli latinan 'civic'-termi, kansalainen, ja sivistymiseen liittyi yhteenkuuluvuuden tunteen herättäminen itsekkään omanedun tavoittelun sijasta. Sivistyminen rinnastui tällöin kansalaisuuteen kasvamiseen. (Arola 1996, 58-60; Ikonen 2002, 107; Nikander 1998, 122.) Anne Ollila (1993, 33) on marttajärjestöä koskevassa tutkimuksessaan havainnut, että sivistykselle annettu merkitys muuttui 1800-luvulta 1900-luvun alkuun siten, että kun 1800-luvun alussa sivistys tarkoitti tiettyä koulutusta, eettisiä ihanteita ja hyvien käytöstapojen omaksumista, tuli 1900-luvun alussa keskeiseksi sivistyksen peruselementiksi taloudellinen toiminta ja kyky kohottaa hyvinvointia ahkeruuden, yritteliäisyyden ja työteliäisyyden avulla. Tämänlaatuinen sivistys nähtiin välttämättömäksi edellytykseksi kansakunnan menestymiselle ja Suomen kohoamiselle muiden sivistysmaiden joukkoon. Hyvän kuvan niin sivistyksen, kuin siveellisyydenkin laajasta merkityksestä antaa seuraava katkelma oppivelvollisuuskomitean mietinnöstä:

“Kyky syrjävaikutuksista huolimatta säilyttää arvostelunsa asiallisuus ja itsenäisyys sekä vielä enemmän kyky syrjäyttää omat persoonalliset etunsa yhteisen hyvän tieltä ovat ominaisuuksia, jotka edellyttävät kehittyneitä siveellisiä luonteenominaisuuksia. Ilman tällaista kansalaissivistystä kaikissa kansankerroksissa on jokainen kansanvaltainen yhteiskuntajärjestys ilmeisesti lujaa perustusta vailla. Vaara sen väärinkäyttämisestä ja menettämisestäkin on suuri ja sitä suurempi, kuta laajempien kansalaiskerrosten kannatuksesta tuo järjestys on riippuva. ”(Kom.1907,1-3.)

Mietinnön tekstistä kuulsi läpi huoli kansalaisoikeuksien "väärinkäyttämisestä”. Suurlakon ja 
sitä seuranneen eduskuntauudistuksen myötä kansalaisvapaudet ja poliittiset oikeudet laajentuivat 1900-luvun alussa koskemaan aikaisempaa laajempia kansankerroksia - länsieurooppalaisittain katsottuna ainutlaatuisen nopeasti. Yhteiskunnallisten ja valtiollisten olojen kehittyminen kansanvaltaisempaan suuntaan asetti uusia vaatimuksia kansalaisuudelle ja vilkas yhteiskunnallinen uudistuskeskustelu nosti myös kansakoulun uudistussuunnitelmat ja kansalaiskasvatuksen voimallisesti esiin.

\section{AMMATILLINEN, YLEISSIVISTÄVÄ VAI POLIITTINEN KANSALAISUUS?}

Kansalaiskasvatuksen kysymykset saivat erityisen painoarvon Suomen valtiollisen itsenäistymisen ja sitä edeltäneen kansalaissodan myötä. Suomen opettajayhdistyksen kokoontuessa vuosikokoukseensa Helsinkiin syyskuussa 1918 opettajakunta oli pettynyt ja tyrmistynyt kasvatustyön epäonnistumisesta:

Kuluneen talven kaameat verityöt ovat todentaneet sivistyksemme onttouden. Se on ollut ainoastaan lukutaitoa, vailla arvostelukykyä ja yksilöllisyyttä. Tällä asteella ollen on ollut mahdollista se, mikä on tapahtunut. Suurista joukoista on muodostunut laumaihmisiä, joukkohulluja, jotka ovat sokeasti uskoneet mitä mahdottomimpia ja olleet valmiit tottelemaan sydämettömiä johtajiaan, käskivätpä ne minkälaisiin tekoihin tahansa." (Opettajain Lehti 1918, 353.)

Myös lääke oli yhtä selvä: kasvatustyötä oli tehostettava ja puutteellisuuksia korjattava. Kansalaissodan kaltaisten tapahtumien välttämiseksi katseet kohdistettiin kansalaiskasvatukseen ja erityisesti nuorison kasvatusta, jatko-opetusta, tehostamalla haluttiin turvata nousevan polven luottamus yhteiskuntajärjestystä kohtaan. Opettajayhdistyksen kokouksessa ehdotettiin jatkoopetuksen pidentämistä kolmivuotiseksi nuorisokouluksi, joka olisi pakollinen kaikille ansiotyöhön siirtyville nuorille. Jatkokoulut tuli perustaa erikseen pojille ja tytöille, ja opetuksen tuli perustua ammatilliselle ja yhteiskunnalliselle pohjalle. Opetuksen tuli kehittää vastuuntunnetta, kansalaisen velvollisuuksien ymmärtämistä, tietoja yhteiskunnan toiminnasta ja välineitä oman tai ryhmän etujen ajamiseen ilman että rikotaan "korkeampaa valtiollista kokonaisuutta ja jär- jestystä." (Opettajain Lehti 1918, 353-354.)

Nämä opettajakunnan esittämät jatko-opetuksen tavoitteet toteutuivat osittain oppivelvollisuuslaissa. Siinä kaksivuotinen jatko-opetus säädettiin pakolliseksi niille, jotka eivät käyneet kansakoulun jälkeen muita kouluja. Jatko-opetuksen liittäminen oppivelvollisuuteen merkitsi valtiollisen koulutusjärjestelmän kasvatusvastuun ulottamista 13-14-vuotiaisiin. Vuonna 1922 mietintönsä julkaissut jatko-opetuskomitea perusteli koulunkäynnin pidentymistä sillä, että yhteiskunnan tuli entistä enemmän ottaa vastuuta nuorten sosiaalistamisesta. Kodit eivät voineet taata riittävää kansalaiskasvatusta ammatillisesta valmennuksesta puhumattakaan. Kansakoulun jatkoksi tarvittiin varhaisnuorten koulua, jossa nuoret saivat uskonnollista ja siveellistä kasvatusta, kansalaiskasvatusta, ruumiin kasvatusta ja valmistusta ammattiin. Työtä tekevän kansalaisen tuli omata hyvä ammattitaito, yhteiskunnalliset ja siveelliset hyveet sekä riittävä yleissivistys: "Kunnon ammattilainen on myös kunnon kansalainen ja ihminen.” (Kom. 1922, 3, 7.)

Jatko-opetuksen liittäminen oppivelvollisuuteen merkitsi nuorison systemaattisen nuorisokasvatuksen tärkeyden ja merkityksen tunnustamista. Samalla käynnistyi useita vuosikymmeniä kestänyt vaihe, jonka aikana tälle koulumuodolle etsittiin oikeaa suuntaa ja sisältöä. Jatko-opetuksen kiistanalainen "paikka" koulutusalojen välimaastossa näkyi selvästi sekä kansakouluväen keskinäisissä kiistoissa että tämän koulumuodon niveltymisessä varsinaiseen ammatilliseen koulutukseen. Osa kansakouluväestä halusi viedä nuorisoasteen koulua lähemmäksi ammatillista koulutusta ja osa taas katsoi paremmaksi kiinnittymisen kansakouluasteeseen ja yleissivistävään opetukseen. Koulun sisällä käytiin kiistoja siitä, tuliko opetuksen sisällöissä painottaa käytännöllisiä taitoja vai yleissivistäviä lukuaineita. Käytännöllisen opetuksen kannattajat näkivät koulun muodostuvan oppilaille hyödylliseksi ja kotien hyväksymäksi vain siinä tapauksessa, että se pystyi tarjoamaan elämässä hyödyllisiä tietoja ja taitoja. Yleissivistävän jatkokoulun kannattajat taas vieroksuivat hyötypainotteista käytännöllistä opetusta ja halusivat tarjota ruumilliseen työhön sijoittuville nuorille eväitä henkiseen kasvuun ja maailmankatsomuksen muodostamiseen. Nämä kaksi tavoitetta asettuivat siis usein vastakohdikseen: hyödyllisyys ja henkinen kasvu löivät toisiaan korville. 
Varsin yleinen oli käsitys jatkokoulun elinkeinoelämää palvelevasta luonteesta. Tällöin oppiaineetkin tuli valita kunkin paikkakunnan elinkeinoelämän tärkeimpien haarojen mukaan, mikä maaseudulla tarkoitti luonnollisesti maataloutta. Kunnalliselämän monipuolistuminen tuotiin esiin yhtenä jatkokurssien sisältöön vaikuttavana tekijänä. Valistuneen kansalaisen tuli ottaa osaa kunnalliseen elämään ja ymmärtää esimerkiksi osuustoiminta-aatetta. Jatko-opetuksen oppiaineeksi esitettiin mm. kunnallisoppia, jossa perehdyttäisiin kunnallisasetukseen ja kansakouluasetukseen. Myös asioimiskirjoitusta ja yksinkertaista kirjanpitoa oli opetettava, jotta jokainen kansan mies ja nainen osaisi pitää kirjaa tuloistaan ja menoistaan. Osa jatkokoulun opettajista oli valmis kokeilemaan varsin ennakkoluulottomasti niin elinkeinoelämään kuin kansalaiselämään liittyviä käytännönläheisiä opetussisältöjä. (Jauhiainen 2002, 73-77.)

Yhteiskunnallinen kasvatus mainittiin usein jatko-opetuksen perimmäisenä päämääränä käytännöllisen opetuksen ohella. Tämä tavoite sai kansalaissodan jälkeen entistä tärkeämmän merkityksen ja jatko-opetuksen toivottiin opettavan nuorisolle yhteiskuntarakennetta ja sitä kautta kehittävän omakohtaista yhteiskuntatietoisuutta. Yhteiskunnallisen kasvatuksen toteuttaminen ei kuitenkaan ollut helppoa ja esimerkiksi yksi jatko-opetuksen keskeisimmistä runkoaineista, yhteiskuntaoppi, osoittautui vaikeaksi aineeksi niin opettajille kuin oppilaillekin. Yhteiskuntaoppia pidettiin yleisesti tämän ikäisille liian abstraktina ja vaikeatajuisena oppiaineena. Opettajat valittivat, että yhteiskunnalliset asiat eivät vielä kiinnostaneet jatkokouluikäisiä ja ainetta oli vaikea opettaa tarpeeksi käytännönläheisesti. (Opettajain Lehti 1928, 449-451, 497-500; Uudistuva kasvatus- ja opetustyö 1931, 150; Opettajain Lehti 1935, 538-539; Opettajain Lehti 1937, 131-132.)

Sisäisten erimielisyyksien lisäksi suhteiden järjestäminen ja rajan vetäminen ammattiopetukseen muodostui koulutuspoliittiseksi ongelmaksi, jonka ratkaiseminen kesti vuosikymmeniä. Ennen oppivelvollisuuden säätämistä jatkokoulut ja ammatilliset koulut toimivat rinnakkain ja valinta niiden välillä tapahtui usein sukupuolen perusteella: tytöt kävivät jatkokoulua ja pojat ammatillista koulua. Suhde ammatilliseen opetukseen kärjistyi nimenomaan jatko-opetuksen pakollisuuden myötä, kun jatkokoulut ja ammattikoulut joutuivat keskenään kilpailuasetelmaan.
Huolimatta kansakoulun sisäisistä linjaerimielisyyksistä kasvattavan ja ammatillisen suuntautumisen välillä kansakoulu piti suhteessa ammatilliseen kenttään tiukasti kiinni omasta kansalaiskasvatuksen reviiristään. Ainakin yhtä tiukasti, ellei tiukemminkin, ammattikouluväki varjeli vielä muotoutumassa olevaa ammattiin kasvattamisen reviiriään ja suhtautui hyvin epäluuloisesti jatko-opetuksen käytännöllistämispyrkimyksiin. Molemmat osapuolet katsoivat nuorisokoulutusta omasta näkökulmastaan: kansakouluväen keskuudessa painotettiin kansalaiskasvatusta, ammattikoulua edustavissa piireissä taas mahdollisimman tehokasta ammattiopetusta. (Jauhiainen 2002, 125-130; ks. myös Heikkinen 1995, 242-243; 204-206.)

\section{KOTI JA PERHE KANSALAIS- YHTEISKUNNAN ALKIONA -OHJELMA}

Suomessa jatkokoulusta muodostui alkuvuosikymmeninään nimenomaan tyttöjen koulu, jossa perheen ja kodinhoitoon liittyvillä aineilla oli keskeinen sija. Varsinaisen kotitalousideologian läpimurto on ajoitettu Suomessa 1920-luvulle, mutta erityisesti kaupungeissa kotitaloudella oli tyttöjen jatko-opetuksessa tärkeä asema 1800-luvun lopulta lähtien.

Helsingin jatkokoulun opettaja Olga Moberg arvioi 1910-luvun puolivälissä kotitalouden vakiinnuttaneen paikkansa täysin tyttöjen jatkoopetuksessa yhtenä tärkeimpänä aineena, jolle vanhemmat antoivat niin suuren merkityksen, että lähettivät lapsensa kouluun juuri tämän aineen takia. Moberg näki kotitalousopetuksen antavan myös ammatillisia valmiuksia kotiapulaisiksi hakeutuville tytöille:

"...helpottaa se monille köyhille tytöille olemassaolon taistelua, valmistaen heitä koulunsa päätettyään perheapulaisiksi hyviin koteihin iässä, jolloin heidän on vielä vaikea tietää taipumuksiaan. Asiatytön ruumiin- ja sielunvoimia kuluttava toimi on viime aikoihin asti ollut kansakoulusta päässeiden tyttöjen pääasiallisin ala. Siinä he eivät opi niitä tietoja ja taitoja, joita tuleva koti tarvitsee, ja mikä pahinta - kotoisiin tehtäviin tuskin enää kasvaa halua ja harrastusta, kun sitä ei ole lapsena herätetty.” (Kasvatus ja koulu 1915-16, 13-14, 19.)

Kotitalousopetuksen taustalla voidaan nähdä sivistyneistön kasvava huoli alempien yhteis- 
kuntaluokkien lapsista ja nuorista. Työläisnaisten kykyä kasvattaa lapsensa ja hoitaa kotinsa epäiltiin esimerkiksi parempiosaisten naisten toimintakentiksi kohoavissa nais- ja kansalaisjärjestöissä. (Häggman 1994, 197; Markkola 1994; Ollila 1993; Sulkunen 1987.) Niinpä työväestön tyttöjen katsottiin tarvitsevan erityistä ohjausta ja opastusta kotitalousaskareisiin ja taloudenhoitoon. Myös sosiaalistamistehtävä oli tärkeä: kotia ja kodin töitä oli opittava arvostamaan ja näin tyttöjen jatko-opetuksen tavoitteet ja sisällöt kytkeytyivät selkeästi työläisperheen naisille sovitettuun naisideaaliin.

Yhteissuomalaisessa koulukokouksessa vuonna 1921 puhuneen vapaaherratar Ida YrjöKoskisen puheenvuoro on hyvä esimerkki siitä, millaisia laajempia yhteiskunnallisia merkityksiä kotitalousopetukseen oppiaineena liitettiin. YrjöKoskinen oli huolissaan kotien rappeutumisesta, naiset kävivät töissä kodin ulkopuolella ja koulu tahtoi vierottaa lapset kodin piiristä. Kun työläistytöt kotitaloustunneilla opetettiin hoitamaan kotiaan ja pitämään se järjestyksessä, vaikutettiin välillisesti myös yhteiskunnallisiin oloihin:

"Viime vuosien vaikeat myrskyt johtuvat luultavasti osaksi vaillinnaisista kotioloista tai oikeastaan kodin puutteesta, ihmisarvoisten kotien puutteesta...Järjestys kodeissa tuo järjestysmieltä myöskin yhteiskuntaan...Sairas aikamme tarvitsee monenlaista lääkitystä yhteiskuntaolojen parantamiseksi ja uskon varmasti pakollisen talousopetuksen olevan tässä suhteessa parhaita ja tehoisimpia. Tälle opetukselle on annettava tarkka ohjelma, ettei se syrjäydy tarkoituksestaan ja muutu ruokaturhuuden ja ylellisyyden palvelijaksi", (Kansakoulun Lehti 1921,215-221.)

Kotitalousideologian läpimurto 1920-luvulla merkitsi sitä, että kotitalousopetus otettiin kaikkien tyttöjen opetusohjelmaan niin kansa-, jatko, ammatti- kuin oppikouluissa. Irma Sulkunen ja Mervi Kaarninen ovat liittäneet kotitalousideologian läpimurron Suomessa kansalaissodan jälkiseurauksiin. Kansalaissota lisäsi sivistyneistön epäluuloa erityisesti työväestön äitejä kohtaan. Yleinen suhtautuminen naisten ansiotyöhön muuttui ja pelättiin perheiden rikkoutumista ja lasten kasvatusvaikeuksia. Tyttöjen kasvatuksessa alkoi korostua äitiystehtävä. Kotitalousideologiaan kytkeytyi myös sosiaalipoliittisia ja alem- piin väestöryhmiin kohdistuvia kontrolli- ja säätelyintressejä. Yhteiskuntarauha haluttiin palauttaa perheiden kautta kohottamalla naiset äiteinä, kasvattajina ja perheenemäntinä avainasemaan. (Kaarninen 1995, 247; Sulkunen 1989, 82-83.)

Kotitaloustaitojen opettamisessa ei siis ollut kysymys pelkästään käytännöllisten taitojen oppimisesta. Samalla kun opittiin keittämään, paistamaan, leipomaan ja pyykkäämään, opittiin myös huolellisuutta, kaunista käytöstä ja rakkautta kotiin. Perimmäinen päämäärä myös kotitalousopetuksessa oli lujan siveellisen luonteen kasvattaminen, kuten käy ilmi seuraavasta Nanny Lundgrenin kirjoituksesta:

"Siinä on todellakin tilaisuutta opettaa hyviä tottumuksia ja kauniita tapoja. Siinä saa rajua hillitä, hidasta innostaa, arkaa rohkaista, kehottaa, käskeä ja varottaa, terottaa silmää siisteyteen, harjottaa kättä järjestykseen. Siinä voi helposti ja havinnollisesti osottaa kuinka työ tekijäänsä palkitsee tai rankaisee, huomauttamalla, kuinka työn onnistuminen tuottaa ahkeralle ja huolelliselle parhaan ilon ja kiitoksen, ja toisaalta näyttämällä, kuinka huonosti tehdystä pilkistää esille huolimaton, huono luonne. Tuo opetus painuu varmasti mieleen. Hyviä tapoja totuttamalla pyritään siis tässäkin opetuksessa lujan siveellisen luonteen kasvattamista edistämään." (Kasvatus ja koulu 1915-1916,69.)

Voidaan ajatella, että erityisesti kansalaisyhteiskunnan muotoutumisen myötä naisista tuli perheenäiteinä "strategisesti tärkeitä". Kun oli tarkoitus tuottaa "laadukkaita" kansalaisia, oli kiinnitettävä huomio tyttöjen, tulevien perheenäitien kasvatukseen. Kotikulttuurin tason nousun uskottiin heijastuvan myös kansantalouteen. Tässä mielessä tyttöjen jatko-opetuksen käytännön aineet: käsityöt, kotitalous ja lastenhoito kasvattivat tyttöjä perheeseen ja kotiin tiukasti kytkeytyvään naiskansalaisuuteen. Rakkaus kotiin merkitsi myös rakkautta isänmaahan. (Jauhiainen 2002, 271-272; ks. myös Johansson 1987.)

Niin kotitalousopetuksen, kuin yleensäkin käytännöllisten aineiden luonnetta kehittävästä ja kotikulttuuria kohottavasta vaikutuksesta muistutettiin vuosikymmenestä toiseen Opettajain lehdessä. Sekä tytöt, että pojat oli saatava innostumaan kodin töistä ja tehtävistä ja omaksumaan terveelliset ruokatottumukset ja säästäväinen asenne taloudenpitoon. (Jauhiainen 2002, 
153-157; 212-214.) Mervi Kaarninen on nähnyt kotitalous- ja maatalousoppiaineissa tiivistyvän koko suomalaisen sotienvälisen kauden yhteiskuntapolitiikan: siisti, hyvin hoidettu ja valoisa koti oli kansalaiskelpoisuuden mitta ja yhteiskuntakasvatuksen keino. (Kaarninen 1995, 42, 46-48.) Tyttöjen jatko-opetuksessa kodinhoidon, käsitöiden, lastenhoidon, terveysopin, ravinto-opin, kirjanpidon, ruokatalousopin ja yhteiskuntaopin tuli yhdistyä suureksi kotikulttuurikysymykseksi. Ammatillinen ruoanvalmistus ei saanut muodostua kotitalousopetuksen päämääräksi, vaan toimia pikemminkin välineenä, jolla herätettiin kiinnostus kotitaloudellisiin kysymyksiin. (esim. Opettajain Lehti 1929, 471-472.)

\section{KANSALAISKOULUN OMA MISSIO: TYÖN AVULLA KUNNOLLISIKSI KANSALAISIKSI}

\begin{abstract}
"Kun kansakoulusta teoreettiseen opiskeluun taipuvimmat ovat jo 4. luokan jälestä tai sitten päästötodistuksen saatuaan siirtynyt ammattikouluun, eivät ne, jotka jatkoluokille joutuvat, ole tietopuoliseen opiskeluun erityisen innostuneita, eikä heitä ensisijassa sillä voida kouluun kiinnittää. Se puoli, jolla heihin voi tarttua ja vetää heidät kouluun kiin$n i$, on ensi sijassa käytännöllinen työ. Se vastaa heidän toiminnan ja työskentelyn tarvettaan, ja sillä heidät parhaiten valloitetaan ja kiinnitetään koulutyöhön, jossa sitten käytännöllisen työn ohella voidaan tarpeellista tietopuolistakin opetusta antaa. Työ on näin lähtökohtana, se on kasvatusvälineenä, ja se on osaltaan myös päämääränä. Työn avulla kunnollisiksi kansalaisiksi, työn avulla valmistumista ja ohjausta käytännöllisen elämän vaatimuksia ja toimeentulovaatimuksia varten - siinä tärkeä näkökohta jatkoluokkien opetusohjelmassa." (Kansakoulun Lehti 1929, 154-155.)
\end{abstract}

Yllä oleva katkelma kuvaa hyvin sitä merkitystä, joka käytännölliselle työlle annettiin jatkokoulussa ja myöhemmin kansalaiskoulussa. Kansalaiskoulun voi siten ajatella jatkaneen suomalaiseen kansansivistyslaitokseen alun alkaen kuulunutta tiivistä kytkentää käytännön työn maailmaan, jossa kansalaisuuden perustana oli rakkaus työhön. Esimerkiksi kansainvälisesti katsottuna harvinaislaatuisen runsas käsityökasvatus oli suomalaisen kansakoulun erityispiirteitä. (ks. Kivinen \& Rinne 1993, 222-225.)

Käytännölliset taidot ja ammatillisuus saivat yleissivistävän koulun sisällä erilaisen merkityksen kuin varsinaisissa ammattikouluissa. Poikien ammatillisten aineiden, kuten puu- ja metallitöiden opetukseen liitettiin samantapaisia kasvatuspäämääriä kuin kotitalousopetukseen. Käden taitojen karttuessa työnopetuksen yhteydessä poikiin tuli istuttaa järjestelmällisyyden, huolellisuuden ja taloudellisuuden ituja. Varsinaisia ammatillisia taitoja keskeisempiä olivat kasvatus ahkeruuteen ja työteliäisyyteen. Erityisesti poikien kohdalla kansakoulun jatko-opetukseen liittyi myös erityisiä nuoren työvoiman suojelutehtäviä. Poikien pelättiin ajautuvan suoraan kansakoulun penkiltä tilapäistöihin ja vähäistä ammattitaitoa vaativiin sekatöihin. Toinen mahdollisuus oli se, ettei töitä löytynytkään, jolloin nuorten pelättiin vieraantuvan kokonaan työelämästä säännöllisen päivärytmin puuttuessa. Joutilaisuus ja ammattitaidottomuus muodostivat häiriötekijän, joka vaaransi säännölliselle palkkatyölle perustuvan yhteiskunnan jatkuvuuden. Kunnon kansalaisuuden mittana oli ahkera, itsensä ja perheensä elättävä ammattilainen. (Jauhiainen 2002, 214-215.)

Myös Suomessa oli kiinnostusta saksalaisen Georg Kerschensteinerin pedagogiikkaa ja yleisemminkin työkouluaattetta kohtaan. Ammatillisuus ja työkasvatus kytkeytyivät Kerschensteinerin pedagogiikassa tiiviisti siveellisen luonteen muodostukseen ja kansalaiskasvatukseen. Työn oli kehitettävä myös henkisiä ominaisuuksia sekä tarkkuutta, kestävyyttä ja siisteyttä. Ihanteena oli toiminnallisuuteen ja työhön suuntautunut koulu, joka toimisi tämän periaatteen mukaisesti aina ensimmäisestä kansakoululuokasta jopa korkeaasteelle saakka. Kerschensteinerilaisessa ammattilinjoittain jakautuneessa jatkokoulussa teoreettinen opetus ja kansalaiskasvatus yhdistyivät läheisesti tiettyyn ammattialaan ja oppilaiden käytännölliseen kokemuspiiriin. (Harju 1988, 306-307; Heikkinen 1995, 387; Kansakoulun Lehti 1908, 422-429; Opettajain Lehti 1914: Työ- ja taidekasvatusliite, 9-12.)

Suomessa Tampereen jatkokoulun pitkäaikainen johtaja Otto Sillantie peräänkuulutti nuorisopsykologisen tutkimuksen huomioimista nuorisokasvatuksen sisältöjä ja päämääriä määriteltäessä. Nuoruusiän herkkyys ja ihanteellisuus olivat perustana myös kansalaiskasvatukselle. Ihminen 
ei elänyt pelkästään leivästä ja nuorisokasvatuksen tuli olla jalostavaa ja kehittävää toimintaa:

"Teollisuuskaupungin nuoret kärsivät ihanteellisuuden nälkää. Tehtävänsä ymmärtävän koulun tulee ensi sijassa sitä tyydyttää. Oppimistyö on johdettava tunnearvoja herättävään suuntaan. Herättäkäämme nuoret rakastamaan heidän omaa, paljon kärsinyttä, mutta nyt kuitenkin vapaata ja itsenäistä isänmaatansa, johtakaamme heidät innostumaan kulttuurin parhaimmista ja korkeimmista ilmaisumuodoista, tieteestä, taiteesta ja uskonnosta! Mutta kaikki tämä on esitettävä nuorille nykyaikaisella käytännöllisellä tavalla.” (Uudistuva kasvatus- ja opetustyö 1937, 13.)

Aksel Kurki ${ }^{4}$ oli samoilla linjoilla Sillantien kanssa liittäessään kansalaiskasvatuksen välttämättömyyden työväestön henkisiin tarpeisiin. Työväenkysymys oli Kurjen mukaan sielun kulttuurin kysymys. Kurki katsoi kuitenkin kerschensteinerilaiseen tapaan, että ammatin tuli olla kaiken jatkokouluopetuksen keskeisenä lähtökohtana, sillä ammatti muovasi monella tavalla ihmistä, hänen elämän- ja maailmankatsomustaan, suhtautumistaan yhteiskuntaan, isänmaahan ja valtioon. Ammattisivistys ei saanut kuitenkaan jäädä ammattitekniikan opettamisen asteelle, vaan todellisen ammattilaisen oli ymmärrettävä laajemmin ja syvällisemmin omaa ammattialaansa ja sen kytkeytymistä muuhun yhteiskuntaa, jolloin kansalaiskasvatus liittyi niin ammattityön opetukseen, yhteiskuntatietoon kuin yleiseen siveysoppiin. Ihanteena oli älykäs, työtänsä rakastava ja siinä itsenäisesti edistyvä ja kehittyvä ammatinharjoittaja. (Kurki 1941, 40-44; 48-51.)

Jatkokoulussa, jossa opetettiin käytännöllisiä taipumuksia omaavia yksilöitä, tuli lähteä käytännöllisestä ammattityöstä ja liittää siihen teoriaa tarpeen vaatiessa. Teorian tarpeen tuli siis herätä käytännön työn kautta ja opetuksella vastattiin juuri niihin kysymyksiin, joita käytäntö herätti oppilaassa. (Kurki 1941, 43.) Vetoamalla mm. Deweyiin ja Kerschensteineriin Kurki painotti, että työ oli luonnetta kehittävää toimintaa:

"Jo jokapäiväinen kokemuskin osoittaa epäilemättömän varmasti, että ihminen on yleensäkin keskittänyt voimakkaimmat tunteensa arkiseen elämäänsä ja elämäntyönsä tarkoituksiin. Jos siis ylläpidämme, hoivaamme ja voimistamme näitä tunteita oppilaassa, niin on meillä hänen luottamuksensa, ja silloin voimme menestyksellisesti elvyttää hänessä jo virinnyttä työnhalua sekä samalla vähitellen henkistää ja jalostaa sen perustana olevia motiiveja. Ja kun täten olemme saavuttaneet hänen täydellisen luottamuksensa, niin voimme ohjata hänet, ei vain kunnon käsityöläiseksi, kauppa-apulaiseksi, kotiapulaiseksi, maanviljelijäksi jne. vaan myös kelpo kansalaiseksi ja yleensä kunnon ihmiseksi, persoonallisuudeksi, joka ei enää aseta omaa etuaan yhteisen edun yläpuolelle." (Kurki 1941,21.)

Kun jatkokoulusta 1950-luvun lopulla kehittyi kansalaiskoulu, määriteltiin tämän koulumuodon erityisluonnetta ja vahvuutta juuri koulun käytännöllisyyden kautta. Kansalaiskoulun erityisluonteesta ja “oppilasaineksesta” käydyssä keskustelussa etualalla olivat pojat, jotka 1950-luvun aikana alkoivat muodostaa enemmistön oppilaista. Uudessa kansakoululaissa (SA 247/1957) jatko-opetus sai vakiintuneen muodon kansakouluun liittyvänä kansalaiskouluna, oman jatkokouluasteelle erikoistuneen opettajakunnan ja viralliset säännökset jatko-opetuksen pakollisista oppiaineista. Jatko-opetuksen asema koulujärjestelmän osana selkiytyi, kun suhteet ammattiopetukseen järjestettiin. Kansalaiskoulusta tuli ammattiopintoihin valmentava "väliaste", jossa ammatinvalinnanohjaukseen alettiin kiinnittää erityistä huomiota.

Kansalaiskoulun perusajatus oli sen toiminnallisuudessa. Tietopuoliset oppiaineet tuli sijoittaa työn lomaan, mutta liikaa teoretisointia ja teoriavaltaisuutta oli vältettävä. (Kailanpää 1962, 13, 203.) Taustalla vaikutti kansalaiskoulun oppilaiden luokittelu Homo Fabereiksi, tekemistä harrastaviksi ihmisiksi erotuksena 'sapienseista', tietämistä harrastavista ihmisistä. Homo Fabereita ei kiinnostanut kirjatieto eivätkä älylliset ponnistukset, he olivat työn ihmisiä, jotka työskentelivät selkeiden, näkyvien tulosten ohjaamina. (Opettajain Lehti 1958a, 8, 25; Opettajain Lehti 1964, 5, ks. myös Takala \& Niskanen 1963,33-34.)

Käsitys ikäluokan kahtiajakautumisesta teoreettisesti ja käytännöllisesti lahjakkaisiin oli varsin yleinen eurooppalaisessa koulutuspolitiikassa 1940-luvulla ja näiden kahden ryhmän eriyttäminen sopivassa vaiheessa toisistaan nähtiin pitkään ennen kaikkea pedagogisena kysymyksenä eikä sosiaalisena jakona. (Husen 1996, 156; Husen, Tujnman \& Halls 1992, 46). Suomessa koulujärjestelmäkysymys ratkaistiin sodan jälkeen tavalla, joka säilytti käytännöllisen ja yleissivis- 
tävän linjan kansakoulun sisällä. Jatko-opetuksesta käydyssä keskustelussa korostettiin käytännöllisen linjan sopivuutta niille nuorille, joilla ei ollut älyllisiä edellytyksiä oppikouluopintoihin. Vielä välittömästi sodan jälkeen näiden käytännöllisen tien kulkijoiden katsottiin muodostavan ikäluokan enemmistön, mutta elintason noustessa sotavuosien jälkeen oppikoulun ja erityisesti keskikoulun käyminen yleistyi huomattavasti ja kansalaiskoululaisista alettiin puhua moneen kertaan karsittuna "ikäluokan jakojäännöksenä". (Jauhiainen 2002, 225-226.)

Kansalaiskoulun aktiiviset kehittäjät pyrkivät kuitenkin varsin kunnianhimoisesti muokkaamaan juuri Homo Fabereille soveltuvaa työn ja toiminnan koulua, jossa haluttiinkin erottautua selkeästi kirjakoulusta, päähänpänttäyksestä ja oppikoulumaisesta ensyklopedismista:

\section{"Kansalaiskoulussa ollaan siitä hyvässä ase- massa, että vaikka oppikoulu on karsinut jou- kosta teoreettisesti lahjakkaan aineksen, mei- dän ei tarvitsekaan tälle jäljellejääneelle osalle ajaa tietoa päähän pänttäämällä, vaan voimme tarjota sitä työtä ja toimintaa, jota tä- mänikäinen nuori kaipaa”. (Opettajain Lehti 1958b, 15.)}

Käytännölliseen elämään valmentavana kouluna kansalaiskoululla ei ollut samanlaista tehtävää oppilasaineksensa jatko-opintokelpoisuuden määrittämisessä kuin yleissivistävillä, selkeää lajittelutehtävää suorittavilla keski- ja oppikouluilla. Kun tuotosten ja todistusten vertailtavuus ei ollut keskeistä, mahdollistui väljyys ja valinnanvara opetussuunnitelmissa ja opetusaineissa. Kaikille oppilaille pakollisten yleisaineiden määrä olikin vähäinen ja kunnat saivat suuren vapauden määrätä opetuksen sisällöstä. (Jauhiainen 2002, 261-262.)

Ammatillisluonteisen opetuksen ja työsuoritusten kautta voitiin herättää kiinnostus, harrastus ja myönteinen asenne yleensäkin koulua ja oppimista kohtaan. Työopetus oli kansalaiskoulun ehdoton valtti ja kaiken oppimisen perusta. Työopetuksen myötä voitiin antaa kuin huomaamatta perustietoja ja taitoja sekä ennen kaikkea kiinnostusta niiden oppimiseen. Kun perustietojen merkitys työn onnistumiselle kävi selväksi, asenne tietojen hankintaan ja omaksumiseen oli erilainen kuin teoreettisella oppitunnilla. Työopetuksessa oli myös mahdollisuus kehittää luonnetta, yritteliäisyyttä ja ahkeruutta sekä herättää sosiaalista mielenlaatua: siis antaa kansalaiskas- vatusta. (Opettajain Lehti 1964, 4-7.)

Kansalaiskoulun omalla pedagogiikalla lähestyttiin siis sellaista ammatillisen koulutuksen pedagogista mallia, joka korostaa “teorian" sisältymistä tekemiseen ja toimintaan sekä kehittymistä käytännön taitojen kautta. Opillista sivistystä tavoitteleva koulu on taas perinteisesti kantanut sisällään teorian ensisijaisuutta ja käytännöllisyyden aliarvostusta. (Mjelde 1987, 208-209.)

Kansalaiskoulun historiassa kunnianhimoiset pyrkimykset luoda omaa käytännöllisyydelle ja toiminnallisuudelle rakentuvaa koulumuotoa ja erottautua "kirjakouluksi" nimitetystä oppikouluasteesta näkyivät selvästi vielä 1950-luvulla. Kansalaiskoulusta haluttiin rakentaa laadukas ja opetusohjelmaltaan monipuolinen nuorisokoulu. Yleissivistävän ja sosiaalista nousua lupaavan oppikouluasteen suosio kasvoi kuitenkin niin selvästi, että 1960-luvun kuluessa kansalaiskoulun katsottiin olevan kestämättömässä tilanteessa. Näköpiirissä oli tämän koulumuodon alentuminen selvästi “epäonnistujien” kouluksi. (Jauhiainen 2002, 277.)

Kansalaiskoulun aika olikin lyhyt. Peruskoulu-uudistuksessa kansakoulu, keskikoulu ja kansalaiskoulu sulautuivat yhteen ja kansalaiskoulun edustama koulutusperinne jäi elämään lähinnä käytännönläheisten valinnaisaineiden muodossa. Heterogeenisen oppilasaineksen aiheuttamia ongelmia pyrittiin ratkomaan eriyttämällä opetusta tasokursseilla, joissa suppeimpien kurssien valinta sulki lukiotien kansalaiskoulun tapaan. Peruskoulusta rakentui alkuun koulu, joka säilytti kansalaiskoulun huonoimmat puolet, kuten yleisen jatko-opintokelpoisuuden sulkevan umpiperän, mutta ei omaksunut sen käytännönläheisyyttä ja läheistä yhteyttä työelämään eli alueita, joissa kansalaiskoulu 'kirjakoulun' vastapainona oli parhaiten onnistunut.

\section{LOPUKSI}

Peruskoulu kantoi siis mukanaan tasa-arvoisen ja modernin yksilökansalaisuuden ideaaleja, joihin sisältyi usko kouluoppimisen universaalisuuteen ja koulun kaikkivoipaisuuteen (Simola 1995, 110-114). Siirtyminen pidempään yhtenäiseen peruskoulutukseen ei ole onnistunut häivyttämään suomalaisen rinnakkaiskoulujärjestelmän kannattelemaa yhteiskunnan luokka- ja sukupuolijakoa. Samanaikaisesti koulutuksellisen huono-osaisuuden merkitys on ratkaisevasti muuttunut. Aikaisemmin koulutuksellisen huono-osaisuuden 
kanssa saattoi tulla toimeen ja esimerkiksi vielä 1980-luvun lopulla perusasteen koulutus riitti suurimmassa osassa työvoimatoimistoon ilmoitetuista avoimista työpaikoista. Kymmenen vuotta myöhemmin 1990-luvun lopulla avoimista työpaikoista vain 14 prosentissa riitti perusasteen koulutus, toisen asteen koulutusta vaadittiin yli puolessa ja korkea-asteen koulutusta lähes kolmasosassa työpaikoista. (Suikkanen \& Linnakangas 2000, 100-102, 106.) Toisen asteen koulutuksesta on siis tullut pohjakoulutuksena vähimmäisvaatimus ja samalla vedenjakaja syrjäytymisriskin kannalta (ks. esim. Noste-ohjelma 20032007; Rahikainen 1999, 15).

Sitä mukaa, kun pohjakouluvaatimukset ovat kasvaneet ja elinikäisestä oppimisesta on tullut velvollisuus ja hyve, on entistä tärkeämmäksi noussut kysymys siitä, miten koulujärjestelmä kykenee tarjoamaan taustoiltaan ja tarpeiltaan erilaisille nuorille sopivan kouluttautumisen muodon ja sitä kautta perustan ja mielekkyyden oppimisen elinikäisyydelle. Yhtenä ratkaisuehdotuksena koulutukselliseen syrjäytymiseen - myös laajemmin eurooppalaisessa koulutuspolitiikassa - on nähty opillisten ja ammatillisten jakojen purkaminen ja joustavammat koulutusjärjestelyt koulutuksen ja työn välimaastossa. (Arnman, Kutscha \& Young 1995, 3-4; Komonen 2002, 48-50, 56-57; Laiho 2000, 35-36; Reconciling liberal...1999, 6-18.)

Yhtenäisyyden ja tasa-arvoisuuden ideaali on koulutusjärjestelmässämme pitänyt sisällään akateemisen koulutusperinteen yliarvostuksen. Kansalaiskoulu ja sen varhaiset edeltäjät edustavat koulutushistoriassamme aliarvostettua koulumuotoa, jossa oppimisen mielekkyys pyrittiin rakentamaan nuorten omalle kokemusmaailmalle ja elävälle elämälle. Kansalaiskoulu ja tälle koulumuodolle ominaiset koulutuskäytännöt, joilla pyrittiin toimintakykyisten kansalaisten kasvattamiseen, on syytä säilyttää koulutushistoriaa koskevassa muistissamme.

\section{LÄHTEET}

Johnsson, M. (1899a) Käytännöllisiä suuntia nykyajan kansanopetuksessa. Valvoja, 19, 19-25, 115-124.

Johnsson M. (1899b) Kansanvalistustyön järjestämisestä. Valvoja, 19, 264-280.

Kailanpää, P. (1962) Kansalaiskoulu. WSOY.

Kansakoulukokous 1899. Pöytäkirja, jonka Ni- kolainkaupungissa 15-17 p:nä kesäkuuta 1899 pidetystä yhdennestätoista yleisestä kansakoulukokouksesta laatinut

A.Haapanen. Helsinki 1900.

Kansakoulun Lehti (1901) Piirteitä saavutetusta kokemuksesta kansanvalistustyöstä Kirjoittaja P. K-o., s. 58-63.

Kansakoulun Lehti (1908) Tulevaisuuden koulu - työkoulu. Kirjoittaja Georg Kerschensteiner, s. 413-429.

Kansakoulun Lehti (1921) Kotitalousopetus pakolliseksi oppiaineeksi kansakouluihin. Kirjoittaja Ida Yrjö-Koskinen, s. 215-222.

Kansakoulun Lehti (1929) Jatko-opetuksen uudistus Helsingin suomalaisissa kansakouluissa. Kirjoittaja J. Metsikkö, s. 154-155.

Kasvatus ja koulu (1915-1916) Kotitalous- ja lastenhoito-opetus käytännössä. Kokeiluja Helsingin kansa-ja jatkokouluissa. Kirjoittaja Olga Moberg, s. 13-21.

Kasvatus ja koulu (1915-1916) Keitto- ja talousopetus Kuopion kaupungin kansakoulussa. Kirjoittaja Nanny Lundgren, s. 67-70.

Kom. (1907) Oppivelvollisuudesta. Komiteanmietintö 1907:12 a. Helsinki 1907.

Kom (1922) Jatko-opetuskomitean mietintö. Komiteanmietintö 1922:10. Helsinki 1922.

Kurki, A. (1941) Kansakoulun jatko-opetus ja ammattiopetus.WSOY.

Opettajain Lehti: Työ- ja taidekasvatusliite (1914) Piirteitä työkoulun kehityksestä. Kirjoittaja O. M-e., s. 9-12.

Opettajain Lehti (1918) Uuden Suomen koulu. Kansakoulun jatko-opetuksen uudelleen järjestämisestä (Alustus opettajayhdistyksen vuosikokouksessa Helsingissä). Kirjoittanut Eemeli Kunnas, s 353-354; s. 361-363.

Opettajain Lehti (1928) Huomioita jatkokoulusta. Kirjoittanut Väinö Korpijärvi, s. 449-451, 497-500, 517-520.

Opettajain Lehti (1929) XX yleinen kansakoulukokous, s. 471-472.

Opettajain Lehti (1935) Vähän ensi lukuvuoden jatkokursseista. Kirjoittaja -a-, s. 538-539.

Opettajain Lehti (1937) Maalaiskansakoulun jatko-opetuksen opetusaineet. Kirjoittaja Antti Raitamaa, s. 131-132.

Opettajain lehti (1958a) Miksi keskikoulu kun- 
nallistuu. Kirjoittaja Alfred Salmela, s. 7-8, 25.

Opettajain Lehti (1958b) Kansalaiskoulun työskentelyn suuntaviivoja. Kirjoittaja Aarre Kailanpää, nro 43, s. 14-15.

Opettajain Lehti (1964) Ammatinopetusta edistävän työopetuksen merkitys kansalaiskoulussa. Kirjoittaja Toivo J. Karttunen. nro 34, s. 3-8.

SA 247/1957 Kansakoululaki.

Soininen M. (1911) Kansakoulun jatko-opetuksen uudistus. Ajankysymys kansanopetuksen alalla. Kustannusosakeyhtiö Otava.

Takala, M. \& Niskanen, E. (1963) Kansalaiskoulun oppilaiden asenteet koulua, yhteiskuntaa ja työelämää kohtaan. Jyväskylän kasvatusopillinen korkeakoulu. Kasvatustieteiden tutkimuskeskus 8/1963.

Uudistuva kasvatus- ja opetustyö (1931) Yhteiskuntaopin perustelusta jatkokoulussa. Kirjoittaja K.K.M., s.150-153.

Uuudistuva kasvatus- ja opetustyö (1937) Jatkokoulusta. Kirjoittaja Otto Sillantie, s. 7-13.

\section{KIRJALLISUUS:}

Aapola, S (1999) Murrosikä ja sukupuoli. Julkiset ja yksityiset ikämäärittelyt. SKS.

Arnman, G., Kutscha, G. \& Young, M. (1995)

The Experimental Reform of Upper Secondary Education in Finland. International Evaluation Report. In U. Numminen \& M. Virolainen (eds.) Open School for the Youth. Three European Views on Developing Youth Education in Finland. Ministry of Education. Nuorisoasteen koulutuskokeilut ja ammattikorkeakoulukokeilut. Raportti 5. Helsinki University Press, 3-4.

Arola. O. (1996) Kansalaiskasvatuksella kaaosta vastaan. Teoksessa Koulu ja menneisyys XXXIV. Suomen kouluhistoriallisen seuran vuosikirja, 1996, 57-66.

Englund, T (1986) Samhällsorientering och merborgarfostran i svensk skola under 1900-talet. Kap 1-4. Pedagogiska forskning I Uppsala 65. Pedagogiska institutionen. Uppsala Universitetet.

Halila, A. (1950) Suomen kansakoululaitoksen historia IV. Oppivelvollisuuskoulun alkuvaiheet. WSOY.

Harju, A. (1988) Maalaiskansakoulujen tarkas- tustoimi 1861-1921. Studia Jyväskyläensia 38. Jyväskylän yliopisto.

Heikkinen A. (1995) Lähtökohtia ammattikasvatuksen kulttuuriseen tarkasteluun. Esimerkkinä suomalaisen ammattikasvatuksen muotoutuminen käsityön ja teollisuuden alalla 1840-1940. Tampereen yliopisto. Acta Universitatis Tamperensis A: 442.

Husen, T. (1996) Youth and Adolescence: a Historical and Cultural Perspective. In J. Clark (ed.) James S. Coleman. Falmer Press, 23-31.

Husen, T., Tujnman, A.\& Halls, W.D. (1992) Schooling in Modern European Society. A Report of the Academia Europaea. Pergamon Press.

Häggman, K. (1994) Perheen vuosisata. Perheen ihanne ja sivistyneistön elämäntapa 1800-luvun Suomessa. Historiallisia tutkimuksia 179. Helsinki.

Ikonen, R. (2002) Syrjäytymisen torjuntaa 1800luvulla:osuustoiminta ja kansalaiseksi kasvattaminen. Aikuiskasvatus, 22 (2), 105-113.

Jauhiainen, A. (2002) Työväen lasten koulutie ja nuorisokasvatuksen yhteiskunnalliset merkitykset. Kansakoulun jatko-opetuskysymys 1800-luvun lopulta 1970-luvulle. Turun yliopisto. Annales Universitatis Turkuensis C: 187.

Johansson, U. (1987) Att skolas för hemmet. Trädgårdsskötsel, slöjd, huslig ekonomi och nykterhetsundervisningen i den svenska folkskolan 1842-1919 med exempel från Sköns församling. Umeå Universitetet. Pedagogiska institutionen.

Kaarninen M. (1995) Nykyajan tytöt. Koulutus, luokka ja sukupuoli 1920- ja 1930-luvun Suomessa. Suomen historiallinen seura.

Kivinen, O. \& Rinne, R. (1993) Grundutbildning och medborgarfostran. Medborgarbilden I Finland på 1800- och 1900-talen. Historisk Tidskrift för Finland, 2, 213-232.

Komonen, K. (2002) Vaihtoehtoinen väylä ammatilliseen perustutkintoon. Työkoulumallilla koulutuksellista syrjäytymistä vastaan. Ammattikasvatuksen aikakauskirja 2/2002, 48-58.

Laiho, K. (2000) Välivaiheen koulutusvaihtoehdot eurooppalaisessa perspektiivissä: yhteiset ja erilaiset käytännöt nuorten ammatillisiin opintoihin saattamiseksi. Ammattikasvatuksen aikakauskirja 2/2000, 35-43. 
Markkola P. (1994) Työläiskodin synty. Tamperelaiset työläisperheet ja yhteiskunnallinen kysymys 1870-luvulta 1910-luvulle. Historiallisia tutkimuksia 187. Suomen historiallinen seura.

McCulloch, G (1998) Failing the Ordinary Child. The theory and practice of working-class secondary education. Open University Press.

Mjelde, L. (1987) From Hand to Mind. In D.Livingstone (ed.) Critical Pedagogy and Cultural Power. McMillan.

Nikander, E. (1989) Kansakoulun tavoitteet Uno Cygnaeuksen, J.V. Snellmanin ja Mikael Soinisen tulkitsemina. Teoksessa Koulu ja menneisyys XXVII. Suomen kouluhistoriallisen seuran vuosikirja 1989, 68-90.

Nikander, E. (1998) Kansalaisuus velvoittaa. Maaseudun piiritarkastajat Suomen kansallisen sovun rakentajina vuosina 1921-1939. Tampereen yliopisto. Acta Universitatis Tamperensis 594.

Noste-ohjelma 2003-2007. Opetusministeriö. Saatavilla: http://www.minedu.fi/opm/hankkeet/kohottamisohjelma/nostemuistio.pdf

Ollila, A. (1993) Suomen kotien päivä valkenee... Marttajärjestö suomalaisessa yhteiskunnassa vuoteen 1939. Suomen historiallinen seura:Historiallisia tutkimuksia 173.

Rahikainen, M. (1999) Aikuiskoulutus Suomessa ja muualla Euroopassa. Valtion taloudellinen tutkimuskeskus. VATT-keskustelualoitteita 192.

Reconciling Liberal and Vocational Education. (1999) Report of the European Union Leonardo da Vinci Research Project on Promoting the Attractiveness of Vocational Education (PAVE). Curriculum Devolopment Unit. Dublin.

Rosenqvist, A. (1915) Murrosikä ja kasvatus sielutietellinen ja kokeelliskasvatusopillinen tutkimus. Otava.

Simola, H. (1995) Paljon vartijat. Suomalainen kansanopettaja valtiollisessa kouludiskurssissa 1860-luvulta 1990-luvulle. Helsingin yliopiston opettajankoulutuslaitos. Tutkimuksia 137.

Suikkanen, A. \& Linnakangas, R. (2000) Koulutuksen valtakunta? Teoksessa R. Raivola (toim.) Vaikuttavuutta koulutukseen. Suomen akatemian vaikuttavuusohjelman tutkimuk- sia. Suomen akatemian julkaisuja 2/00, 99-111.

Sulkunen, I. (1987) Naisten järjestäytyminen ja kaksijakoinen kansalaisuus. Teoksessa R. Alapuro, I. Liikanen, K. Smeds \& H. Stenius (toim.) Kansa liikkeessä. Kirjayhtymä, 15-175.

Sulkunen I. (1989) Naisen kutsumus. Miina Sillanpää ja sukupuolten maailmojen erkaantuminen. Hanki ja jää.

\section{VIITTEET}

1. Väitöskirjatutkimus (2002), ks. kirjallisuusluettelo.

2. Tarkastelin väitöskirjassani (Jauhiainen 2002) kansalaiskoulun historiaa yhteiskunnallis-historiallisessa kontekstissa 1800-luvun lopulta 1970-luvulle kysyen, millaisten vaiheiden kautta kansalaiskoulu vakiintui koulutuksen valtaväylältä sivuun joutuneiden rinnakkaiskouluk si ja lopulta hävisi erillisenä koulutusinsituutiona. Tutkimusongelmani koskivat toisaalta kansakoulun jatko-opetuksesta käytyä keskustelua, toisaalta tämän koulumuodon 'tosiasiallista' muotoutumista, instituutiohistoriaa. Lähdeaineistojani ovat olleet komiteanmietinnöt, kansakouluväen aikakauslehdet (erityisesti Opettajain lehti ja Kansakoulun lehti), kokouspöytäkirjat, tilastot, eri paikkakuntien kansakouluhistoriat sekä Turun osalta kansakoulun vuosikertomukset ja kansakoulun johtokunnan pöytäkirjat.

3. Mikael Soinista voidaan luonnehtia monella eri tavalla. 1900-luvun alkupuolella Mikael Soini nen toimi kouluhallituksen pääjohtajana, ministerinä ja kansanedustajana. Aimo Halila on puhunut Soinisesta oppivelvollisuuskoulumme perustamisvaiheen johtavana kansakoulupoliitikkona, jolle erityisesti alakoulu, jatko-opetus ja kansakoulujen rakennustoiminta muodostuivat "sydämen asioiksi". (Halila 1950, 356-359.)

4. Aksel Kurkea (ennen nimenmuutosta Rosenqvist) on Suomessa tituleerattu murrosiän "keksijäksi" (Aapola 1999, 95). Kurki julkaisi jo vuonna 1915 kirjan "Murrosikäinen ja kasvatus", jossa hän määritteli murrosiän epävakaaksi ja erityistä ohjausta vaativaksi ikävaiheeksi (Rosenqvist 1915). 